\title{
FINE NEEDLE ASPIRATION CYTOLOGY AND HISTOPATHOLOGICAL CORRELATION OF NODULAR LESIONS OF THYROID: A STUDY
}

\author{
Shanthi Balaji1, Balakrishnan Kumbalingam², Sai Sridevi Krishna Muthukrishnan ${ }^{3}$, Umamaheswari Karuppanan ${ }^{4}$ \\ ${ }^{1}$ Assistant Professor, Department of Pathology, K. A. P. Viswanatham Government Medical College, Trichy. \\ 2Professor, Department of Pathology, K. A. P. Viswanatham Government Medical College, Trichy. \\ ${ }_{3}^{3}$ Assistant Professor, Department of Pathology, K. A. P. Viswanatham Government Medical College, Trichy. \\ ${ }_{4}^{4}$ Assistant Professor, Department of Pathology, K. A. P. Viswanatham Government Medical College, Trichy.
}

\section{ABSTRACT}

Thyroid swelling being the most common neck swelling, a retrospective study was done to assess the role of Fine Needle Aspiration Cytology in diagnosing the nature of thyroid lesions and comparing its results with histopathological findings. It was observed that FNAC is the investigation of choice in thyroid swellings and has excellent patient compliance, is simple and quick to perform in outpatient department and is cost effective with high degree of sensitivity and specificity.

\section{MATERIALS AND METHODS}

This is a retrospective study comparing cytology and corresponding histopathology reported in 60 cases of nodular thyroid lesions. The statistical analysis included sensitivity and specificity and accuracy in nodular thyroid lesions.

\section{RESULTS}

On cytological examination of the 671 cases, initial diagnosis/impression as non-neoplastic was given for 616 cases (91.80\%) and neoplastic for 47 cases (7.00\%) in which 17 cases (36.17\%) were benign and 28 cases (59.57\%) were given as malignant, 5 cases were reported as suspicious for malignancy and for 5 cases samples were inadequate for a cytological diagnosis. Sensitivity of FNA in non-neoplasm lesions $92.5 \%$, follicular neoplasm $87.5 \%$ and malignancies $68.42 \%$. The specificity of FNA in non-neoplastic lesion is $100 \%$, in follicular neoplasm is $96 \%$ and in malignancy $100 \%$. Accuracy in FNAC for non-neoplastic lesion and follicular neoplasm 95\% and malignancy $91 \%$.

\section{CONCLUSION}

It was observed that FNAC is a vital reliable tool, safe and accurate method to evaluate nodular thyroid lesions. It greatly influences the treatment decision. In spite of accuracy of FNAC in differentiating between benign and malignant lesions, certain pitfalls were highlighted in diagnosing follicular neoplasm, which constitutes a "Gray zone" and papillary carcinoma and follicular carcinoma. We hope that a better understanding of these pitfalls wound help avoiding them in future and will contribute to better patient care.

\section{KEYWORDS}

Thyroid Nodule, FNAC, Accuracy of FNA, Incidence, Sensitivity.

HOW TO CITE THIS ARTICLE: Balaji S, Kumbalingam B, Muthukrishnan SSK, et al. Fine needle aspiration cytology and histopathological correlation of nodular lesions of thyroid: a study. J. Evolution Med. Dent. Sci. 2016;5(52):3353-3358, DOI: $10.14260 /$ jemds/2016/776

\section{INTRODUCTION}

Nodular lesions in thyroid are so common and it presents as solitary or multiple nodules and are mostly benign and cancerous lesions are at the most instance of relatively low malignant potential.

As the incidence of malignancy presenting on nodular lesion is quite low compared with the overall incidence of thyroid nodule, emphasis is placed upon finding diagnostic modalities that may improve the ability to differentiate between benign and malignant lesions.

There is an ongoing debate as to appropriate evaluation and management of individuals with thyroid nodule. A need to address these issues and to provide a clinically applicable and cost effective approach to the evaluation and management of

Financial or Other, Competing Interest: None.

Submission 28-05-2016, Peer Review 10-06-2016,

Acceptance 13-06-2016, Published 28-06-2016.

Corresponding Author:

Dr. Shanthi Balaji,

\#9C/1,

Nachiarpalyam,

Woriur, Trichy-620003

E-mail: kapvpath@gmail.com

DOI: $10.14260 /$ jemds/2016/776
Nodular thyroid lesions have prompted to take up this studyFine Needle Aspiration Cytology and Histopathological correlation in our centre at KAPVG Medical College and Hospital.

The smears were graded as adequate material for cytological diagnosis, non-neoplastic, follicular neoplasms, suspicious for malignancy and positive for malignancy.

False positive and false negative results were compared with other large series of study. Limitations of Fine Needle Aspiration Cytology's in distinguishing cystic thyroid nodules harbouring malignancy, distinction between colloid nodules and follicular neoplasm.

Thus with meticulous sampling, staining techniques and interpretation of cytomorphological features, Fine needle aspiration cytology is a safe and inexpensive tool in the study of thyroid nodules. Observations support strongly that fine needle aspiration cytology should be the initial investigation of thyroid disease and should embrace this diagnostic procedure in the management of thyroid nodules. Several studies on Fine needle aspiration cytology and histopathological correlation of thyroid nodules, studies on cytomorphological pattern, diagnostic pitfalls and diagnostic usefulness were reviewed. 


\section{MATERIAL AND METHODS}

A retrospective study of thyroid nodules, irrespective of age and sex with patients referred from our Hospital during September 2011 to August 2013 was carried out.

The protocol for the purpose of inclusion in this study was history, clinical examination and the thyroid nodule was defined as single clinically palpable discrete lesions involving either lobes or the isthmus of the thyroid gland.

Initial cytological evaluation with fine needle aspiration cytology was done in 761 cases and in which further HPE correlation was done in 60 cases.

Fine needle aspiration cytology was done as per standard guidelines recommended by Svante R. Orell.(1) A minimum 3 aspirates from different areas were undertaken and the smears were fixed in Isopropyl alcohol. Smears were stained with routine Haematoxylin and Eosin as well as Giemsa in a proportion of cases. The smears were interpreted as guidelines of Papanicolaou Society of Cytopathology.(2)

$\mathbf{T h}_{\mathbf{1}}$ : Unsatisfactory smears.

$\mathrm{Th}_{2}$ : Non-neoplastic lesion.

$\mathbf{T h}_{3}$ : Follicular neoplasm.

Th4 : Suspicious for malignancy.

Th5 : Malignancy.

Thyroidectomy specimens subtotal, Hemithyroidectomy and Total Thyroidectomy were fixed in $10 \%$ buffered neutral formalin. In all the specimen type, the extend of operation, overall size, dimensions, presence of the nodules, capsule, cystic lesions and lymph node status were evaluated and documented.

\section{OBSERVATION AND RESULTS}

This study covered 671 fine needle aspiration sample and 60 Histopathological specimens of patient clinically suspected to have nodular thyroid lesions and undergone further surgical procedures.

In 671 FNA cases, 604 were females (90.01\%) with age ranging from 6-66 years (Mean age 36 years) and 67 were males $(9.99 \%)$ with age ranging from 13-75 years (Mean age of 44 years); the clinical cytological features, type of surgery are included.

Table 1 with Fig. 1 shows the age group and sex wise distribution of thyroid nodules referred for FNA. The highest incidence of nodular lesions was observed in the age group of $31-40$ years (31.59\%) followed by $21-30$ years $(38.16 \%)$ and 41-50 years $(19.5 \%)$. But in males the highest incidence was seen around the $4^{\text {th }}$ decade.

\begin{tabular}{|c|c|c|c|c|c|}
\hline \multirow{2}{*}{ Sl. No. } & \multirow{2}{*}{ Age Group } & \multicolumn{3}{|c|}{ No. of Cases } & \multirow{2}{*}{$\%$} \\
\cline { 3 - 5 } & & Female & Male & Total & \\
\hline 1. & $<20$ Years & 63 & 6 & 69 & $10.28 \%$ \\
\hline 2. & $21-30$ & 182 & 7 & 189 & $28.16 \%$ \\
\hline 3. & $31-40$ & 193 & 19 & 212 & $31.59 \%$ \\
\hline 4. & $41-50$ & 107 & 24 & 131 & $19.52 \%$ \\
\hline 5. & $51-60$ & 45 & 7 & 52 & $7.74 \%$ \\
\hline 6. & $>60$ years & 13 & 5 & 18 & $2.68 \%$ \\
\hline \multicolumn{6}{|c|}{ Table 1: Fine Needle Aspiration Cytology } \\
[Age \& Gender Incidence] \\
\hline
\end{tabular}

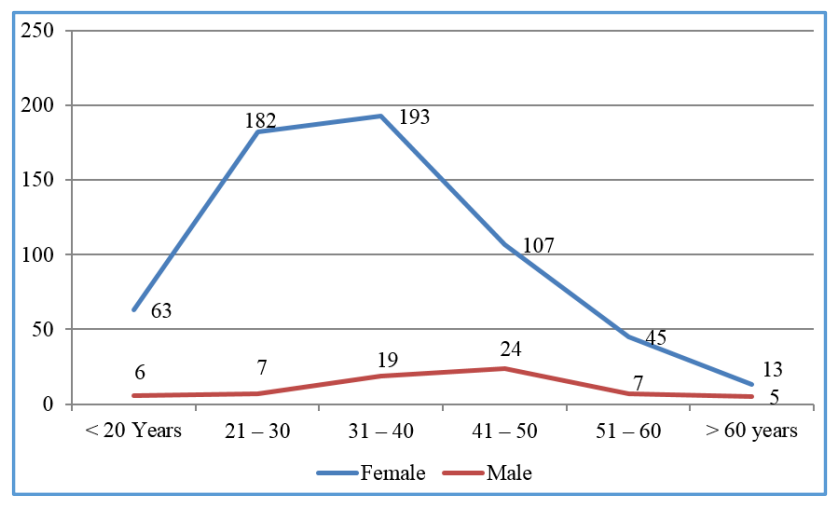

Fig. 1

Similarly, the age distribution of nodular thyroid lesions of 60 cases taken for HPE and Fine Needle Aspiration Cytology correlation were calculated. Table 2 and Fig. 2, which shows increased incidence in the age group of 31-40 years (30\%) followed by age group $21-30$ years $(26.66 \%)$ and $41-50$ years $(21.66 \%)$.

\begin{tabular}{|c|c|c|c|c|c|}
\hline \multirow{2}{*}{ Sl. No. } & \multirow{2}{*}{ Age Group } & \multicolumn{3}{|c|}{ No. of Cases } & \multirow{2}{*}{$\%$} \\
\cline { 3 - 5 } & & Female & Male & Total & \\
\hline 1. & $<20$ years & 6 & 0 & 6 & 10 \\
\hline 2. & $21-30$ & 15 & 1 & 16 & 26.66 \\
\hline 3. & $31-40$ & 18 & 0 & 18 & 30 \\
\hline 4. & $41-50$ & 12 & 1 & 13 & 21.66 \\
\hline 5. & $51-60$ & 3 & 2 & 5 & 8.33 \\
\hline 6. & $>60$ years & 0 & 2 & 2 & 3.33 \\
\hline \multicolumn{5}{|c}{ Table 2: HPE [Age \& Gender Incidence] } \\
\hline
\end{tabular}

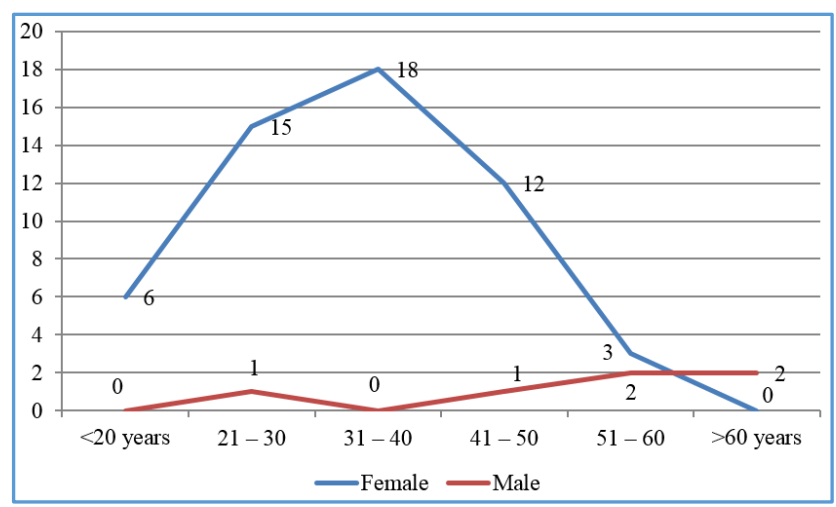

Fig. 2

The FNA cytology of 671 cases was interpreted as nonneoplastic, neoplastic, malignant and suspicious of malignancy and the details mentioned in Table No. 3.

\begin{tabular}{|l|c|c|c|}
\hline $\begin{array}{c}\text { Fine Needle } \\
\text { Aspiration Cytology } \\
\text { Diagnosis }\end{array}$ & $\begin{array}{c}\text { Number } \\
\text { of } \\
\text { Patients }\end{array}$ & \% & $\begin{array}{c}\text { Overall } \\
\%\end{array}$ \\
\hline I. Non-Neoplastic & & & $91.80 \%$ \\
\hline $\begin{array}{l}\text { Nodule of nodular } \\
\text { colloid goitre }\end{array}$ & 423 & $63.04 \%$ & \\
\hline Adenomatous goitre & 26 & $3.87 \%$ & \\
\hline $\begin{array}{l}\text { MNG with cystic } \\
\text { change }\end{array}$ & 167 & 24.88 & \\
\hline & 616 & & \\
\hline II. Neoplastic & & & \\
\hline A. Benign & 16 & $2.38 \%$ & \\
\hline Follicular Neoplasm & $16.53 \%$ \\
\hline
\end{tabular}




\begin{tabular}{|l|c|c|c|}
\hline $\begin{array}{l}\text { Hurthle Cell } \\
\text { Neoplasm }\end{array}$ & 1 & $0.14 \%$ & \\
\hline B. Malignant & 20 & $2.98 \%$ & $4.17 \%$ \\
\hline Papillary carcinoma & 6 & $0.89 \%$ & \\
\hline Medullary carcinoma & 2 & $0.29 \%$ & \\
\hline Anaplastic carcinoma & 5 & $0.75 \%$ & $0.75 \%$ \\
\hline $\begin{array}{l}\text { III. Inadequate } \\
\text { sampling }\end{array}$ & 5 & $0.75 \%$ & $0.75 \%$ \\
\hline $\begin{array}{l}\text { IV. Suspicious for } \\
\text { malignancy }\end{array}$ & Table 3 \\
\hline \multicolumn{3}{|c|}{} \\
\hline
\end{tabular}

Among the 671 cases, initial diagnosis/impression as nonneoplastic was given for 616 cases $(91.80 \%)$ and neoplastic for 47 cases $(7.00 \%)$, in which 17 cases $(36.17 \%)$ were benign and 28 cases $(59.57 \%)$ were given as malignant, 5 cases were reported as suspicious for malignancy and for 5 cases' samples were inadequate for a cytological diagnosis.

Out of the 616 non-neoplastic cases nodule of nodular goitre and simple colloid goitre predominates with 423 cases (63.04\%) followed by multinodular goitre with cystic change 167 cases (24.88\%) and adenomatous goitre 26 cases (3.87\%).

Out of 47 neoplastic cases, benign neoplasm contained 17 cases of which were follicular neoplasm constitute 16 cases (2.38\%) and the rest was a Hurthle cell neoplasm (0.14\%).

28 cases were diagnosed as malignancy, commonest was papillary carcinoma constituting 20 cases $(2.98 \%)$; two cases had lymph node metastasis at the time of diagnosis; 6 cases were diagnosed as medullary carcinoma and 2 cases as anaplastic carcinoma, which had extensive cellularity, nuclear pleomorphism and giant cells in a necrotic background.

Out of 20 cases of cases of papillary carcinoma, 19 (95\%) cases were conventional showing typical papillae with smooth borders, monolayering of follicular epithelial cells with/without nuclear inclusions. One case was reported as follicular variant of papillary carcinoma.

Of 671 cases subjected to Fine Needle Aspiration Cytology, postoperative surgical specimens were obtained only in 60 cases, which were processed for HPE and percentage of incidence in various groups as shown in Table 4.

\begin{tabular}{|c|c|c|c|c|}
\hline $\begin{array}{c}\text { Sl. } \\
\text { No. }\end{array}$ & Thyroid Lesion & $\begin{array}{c}\text { No. } \\
\text { FNA }\end{array}$ & $\begin{array}{c}\text { No. } \\
\text { HPE }\end{array}$ & Percentage \\
\hline 1. & $\begin{array}{c}\text { Non-neoplastic } \\
\text { (NG, CG, Adenoma } \\
\text { Goitre) }\end{array}$ & 616 & 34 & $5.51 \%$ \\
\hline 2. & Follicular neoplasm & 16 & 7 & $43.75 \%$ \\
\hline 3. & Papillary Ca & 20 & 16 & $80 \%$ \\
\hline 4. & Medullary Ca & 6 & 1 & $16.6 \%$ \\
\hline 5. & Anaplastic Ca & 2 & - & - \\
\hline 6. & Follicular Ca & - & 2 & - \\
\hline $\begin{array}{c}\text { Table 4: Shows Percentage Cases in Various Group for } \\
\text { which Cytological Evaluation Were Carried Out } \\
\text { Initially and Subsequent HPE }\end{array}$ \\
\multicolumn{4}{|c}{} \\
\hline
\end{tabular}

\begin{tabular}{|c|c|c|c|}
\hline \multicolumn{2}{|c|}{$\begin{array}{c}\text { Fine Needle Aspiration } \\
\text { Cytology Diagnosis }\end{array}$} & \multicolumn{2}{|c|}{ HPE Diagnosis } \\
\hline MNG & 35 & MNG & 28 \\
\hline AG & 2 & AG & 6 \\
\hline FN & 10 & Follicular Adenoma & 6 \\
\hline & & $\begin{array}{c}\text { HTA (Hyalinizing } \\
\text { Trabecular Adenoma) }\end{array}$ & 1 \\
\hline Pap ca & 12 & Papillary ca & 16 \\
\hline
\end{tabular}

\begin{tabular}{|c|c|c|c|}
\hline Medullary ca & 1 & Follicular ca & 2 \\
\hline & & Medullary ca & 1 \\
\hline Total & $\mathbf{6 0}$ & Total & $\mathbf{6 0}$ \\
\hline Table 5: Shows Fine Needle Aspiration Cytology \\
\& Final HPE Correlation in 60 Cases \\
\hline
\end{tabular}

Out of 60 cases thyroid HPE study showed the following, 34 cases of (56.7\%) non-neoplastic lesions [Nodule of nodular goitre, colloid goitre and adenomatous goitre.]

In the non-neoplastic lesions, most of them were nodule of a nodular goitre 19 cases $(55.8 \%)$ and with toxic change 3 cases $(8.8 \%)$ with cystic change 4 cases $(11.8 \%)$; papillary hyperplasia 1 case $(2.94 \%)$ and 7 cases of adenomatous goitre (20.58\%) were observed.

Out of 26 [43.3\%] cases in neoplastic group, benign follicular adenomas were diagnosed in 6 cases $(23.00 \%)$ and hyalinising trabecular adenoma in 1 case (3.80\%) and 19 cases as malignancy (73.00\%).

Here 6 cases of follicular adenoma with intact smooth capsule and 1 case of hyalinising trabecular adenoma with paraganglioma-like picture was seen.

The Final Histopathological Diagnosis were Tabulated According to the Age Wise Distribution as in Table 6

\begin{tabular}{|c|c|c|c|c|c|c|c|c|}
\hline $\begin{array}{l}\text { Sl. } \\
\text { No. }\end{array}$ & $\begin{array}{l}\text { Age } \\
\text { Group }\end{array}$ & $\sum_{\Sigma}^{5}$ & క & 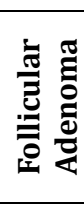 & 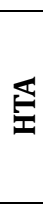 & $\begin{array}{l}\tilde{U} \\
\text { 宝 }\end{array}$ & $\frac{\text { J }}{\mathcal{J}^{\circ}}$ & 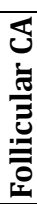 \\
\hline 1. & $\begin{array}{l}<20 \\
\text { Years }\end{array}$ & - & 1 & 2 & 1 & 2 & - & - \\
\hline 2. & $21-30$ & 5 & 3 & 1 & - & 5 & 1 & 1 \\
\hline 3. & $31-40$ & 10 & 1 & 3 & - & 3 & - & 1 \\
\hline 4. & $41-50$ & 7 & - & - & - & 6 & - & - \\
\hline 5. & $51-60$ & 4 & 1 & - & - & - & - & - \\
\hline 6. & $\begin{array}{c}>60 \\
\text { years }\end{array}$ & 2 & - & - & - & - & - & - \\
\hline & Total & 28 & 6 & 6 & 1 & 16 & 1 & 2 \\
\hline
\end{tabular}

Table 6: Shows the Final Histopathological Diagnosis for 60 Cases According to Age

A high incidence of malignant neoplasm was seen in the age group of 21-30 years ( 7 cases, $37 \%$ ), followed by $31-40$ years ( 3 cases, $26.31 \%$ ). Follicular adenoma showed highest incidence in the age group 31-40 years (3 cases, 50\%) followed by less than 20 years ( 3 cases, 33.33\%). Nonneoplastic lesions were found to be more prevalent in 31-40 age group (11 cases, 32\%) followed by $21-30$ years ( 8 cases, $23.5 \%$ ). In malignant lesions 16 cases of papillary carcinoma were diagnosed and 8 cases of papillary carcinoma with lymph node specimen showed deposits of papillary carcinoma in lymph node.

\section{Comparison with Final HPE (Performance Indices)}

The Thyroid FNA results grouped non-neoplastic and neoplastic were compared to results of final histological study of the excised specimen in order to calculate to the values of the test.

\section{Accuracy in FNA in Our Study for \\ 1. Non-neoplastic lesions $95 \%$. \\ 2. Follicular neoplasm $95 \%$. \\ 3. Malignancies $91 \%$.}


The Table 7 shows the sensitivity and specificity and accuracy in nodular thyroid lesions in our study.

\begin{tabular}{|c|c|c|c|c|}
\hline $\begin{array}{c}\text { Sl. } \\
\text { No. }\end{array}$ & Lesions & Sensitivity & Specificity & Accuracy \\
\hline 1. & $\begin{array}{c}\text { Non- } \\
\text { neoplastic } \\
\text { (NG, CG, } \\
\text { Adenoma } \\
\text { Goitre) }\end{array}$ & $92.5 \%$ & $100 \%$ & $95 \%$ \\
\hline 2. & $\begin{array}{c}\text { Follicular } \\
\text { neoplasm }\end{array}$ & $87.5 \%$ & $96 \%$ & $95 \%$ \\
\hline 3. & Malignancies & $68.42 \%$ & $100 \%$ & $91 \%$ \\
\hline \multicolumn{3}{|c|}{ Table 7: Shows Percentage Cases in Various Group for } \\
which Cytological Evaluation were carried \\
out Initially and Subsequent HPE \\
\hline \multicolumn{4}{|c|}{} \\
\hline
\end{tabular}

\section{DISCUSSION}

The present study shows the value, feasibility of initial cytological evaluation of nodular lesions of thyroid followed by histopathological examination confirmation.

The present study shows that the incidence of nodular lesions of thyroid is $15.7 \%$ of the total aspiration and nodular neoplasm of thyroid was $43.35 \%$, which was fairly comparable with studies by Manoj Gupta. (3) were nodular lesions incidence $4-10 \%$ and neoplastic lesions $5-30 \%$. The majority of cases were seen in the age group of 36 yrs. and Female:Male Ratio 8.86:1. Table 8 shows ratio of the comparative study between non-neoplastic and neoplastic lesions, which correlated with our study. Nodular colloid goitre was the most common thyroid lesion in this study with $63.04 \%$. The next commonest in FNA of benign lesion is cystic change (24 88\%).

Among the benign neoplasm our study showed the incidence of follicular neoplasm is $2.38 \%$ and Hurthle cell neoplasm $0.14 \%$ by Fine Needle Aspiration Cytology. The commonest encountered malignancy was papillary carcinoma (Fig. 3 \& 4). About 2.98\%, medullary carcinoma $0.89 \%$ and anaplastic carcinoma $0.29 \%$.

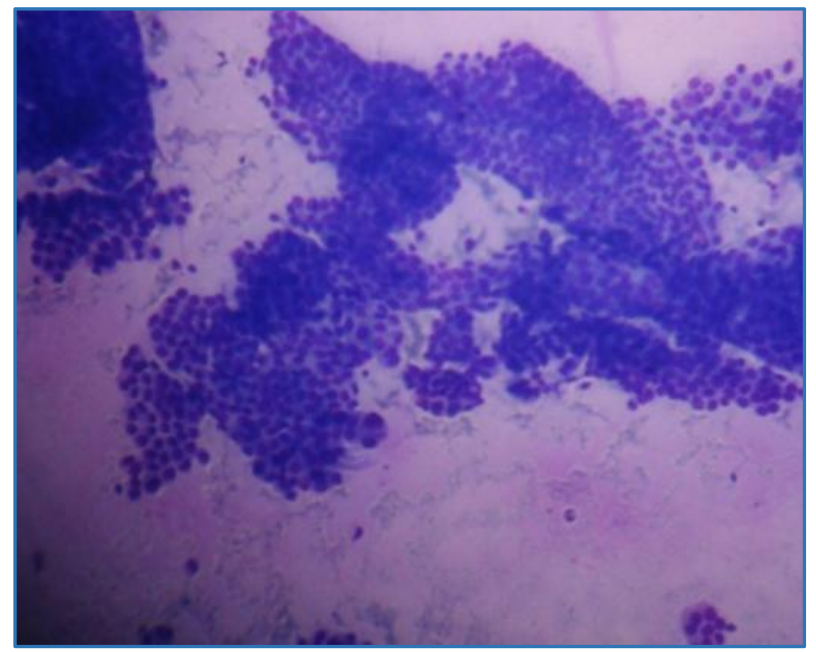

Fig. 3: Monolayered Clusters of Tumour Cells with Papillae in Papillary Carcinoma (GIEMSA Stain HP x 100)

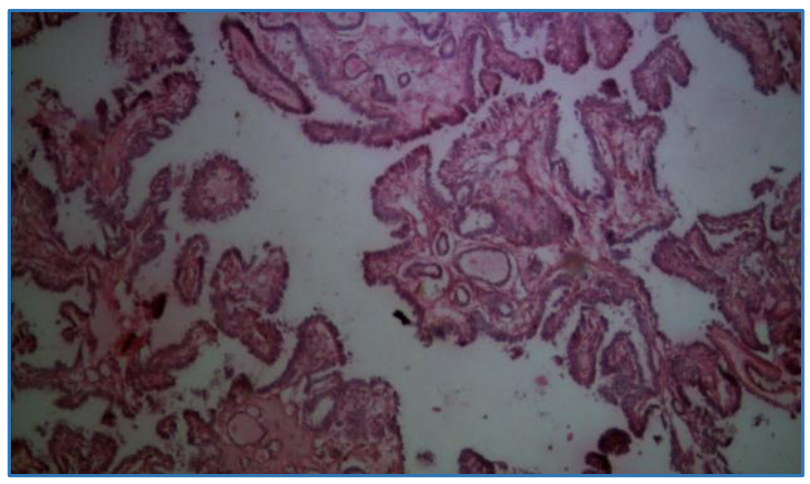

Fig. 4: Classical Papillary Carcinoma of Thyroid H\&E 100

A satisfactory correlation was obtained for nodular goitres and malignancy in our centre as with other studies show in Table 8.

\begin{tabular}{|c|c|c|c|c|}
\hline $\begin{array}{l}\text { Sl. } \\
\text { No. }\end{array}$ & Series & $\begin{array}{c}\text { Non- } \\
\text { Neoplastic }\end{array}$ & Neoplastic & Ratio \\
\hline 1. & $\begin{array}{l}\text { Pepper, } \\
\text { G.M.4 }\end{array}$ & 84 & 18 & $4.66: 1$ \\
\hline 2. & $\begin{array}{l}\text { Dorairajan } \\
\text { N. } 5\end{array}$ & 78 & 20 & $3.90: 1$ \\
\hline 3. & Sarda AK. ${ }^{6}$ & 87 & 59 & $8.25: 1$ \\
\hline 4. & Das DK. ${ }^{7}$ & 346 & 85 & $4.07: 1$ \\
\hline 5. & Gupta C. 8 & .470 & 30 & 15.66:1 \\
\hline 6. & Kaur K.9 & 32 & 15 & $2.13: 1$ \\
\hline 7. & Duek SD. ${ }^{10}$ & 145 & 61 & $2.37: 1$ \\
\hline 8. & $\begin{array}{c}\text { Hurtado- } \\
\text { Lopez LM.11 }\end{array}$ & 80 & 50 & $1.60: 1$ \\
\hline 9. & $\begin{array}{l}\text { Talepoor } \\
\text { M.12 }\end{array}$ & 325 & 75 & $4.33: 1$ \\
\hline 10. & $\begin{array}{c}\text { Nggada } \\
\text { HA. }{ }^{13}\end{array}$ & 51 & 18 & $2.83: 1$ \\
\hline 11. & $\begin{array}{c}\text { Prakash } \\
\text { H.M.14 }\end{array}$ & 138 & 24 & $5.75: 1$ \\
\hline 12. & Our Study & 34 & 26 & $1.30: 1$ \\
\hline \multicolumn{5}{|c|}{ Table 8} \\
\hline
\end{tabular}

A satisfactory correlation was obtained for nodular goitres and malignancy in our centre as with other studies. Four false negative cases of cystic change in nodular goitre were diagnosed as papillary carcinoma in histopathological examination. Chu and Associates suggested the preparation of cell blocks from cystic fluids to minimize risk of missing a papillary carcinoma. ${ }^{15}$

In our study, 7 out of 10 follicular adenomas were diagnosed by FNA correlated with HPE results, whereas 2 cases as follicular carcinoma and one case turned out to be adenomatous goitre and other one showed features of hyalinising trabecular adenoma.

In malignancy papillary carcinoma the diagnostic accuracy was good in 16 cases and 4 cases of papillary carcinoma were given false negative diagnosis of nodular goitre. So the overall diagnostic accuracy of nodular lesions in this study was $93.6 \%$.

The following Table 9 shows the comparison of specificity, sensitivity and accuracy for malignant lesions of thyroid with various authors. 


\begin{tabular}{|c|c|c|c|c|c|c|}
\hline Sl. No. & Series & Total & Operated & Malignant & Sensitivity & Specificity \\
\hline 1. & Gardiner et al ${ }^{16}$ & 1465 & 207 & 46 & 65 & 91 \\
\hline 2. & Hawkins et al ${ }^{17}$ & 1399 & 415 & 73 & 86 & 95 \\
\hline 3. & Khafagi et al 18 & 618 & 258 & 44 & 87 & 72 \\
\hline 4. & Hall et al ${ }^{19}$ & 795 & 72 & 37 & 84 & 90 \\
\hline 5. & Alta villa et al 20 & 2433 & 257 & 49 & 71 & 100 \\
\hline 6. & Caplan et $\mathrm{al}^{2}$ & 502 & 185 & 64 & 91 & 99 \\
\hline 7. & Gharib and Goellner. ${ }^{21}$ & 10971 & 1750 & 682 & 98 & 99 \\
\hline 8. & Aggarwal SK.22 & 36 & 36 & 16 & 68.1 & 100 \\
\hline 9. & Bapat RD. ${ }^{23}$ & 105 & 105 & 6 & 75 & 100 \\
\hline 10. & Gupta C. ${ }^{8}$ & 507 & 145 & 30 & 89.47 & 99.2 \\
\hline 11. & Duek SD.10 & 206 & 206 & 61 & 78.1 & 76.5 \\
\hline 12. & Kaur K. ${ }^{9}$ & 50 & 50 & 5 & 83.3 & 100 \\
\hline 13. & Cap et $\mathrm{al}^{24}$ & 2492 & 536 & - & 86 & 74 \\
\hline 14. & Holleman. ${ }^{25}$ & 130 & 53 & - & 84 & 52 \\
\hline 15. & Mundasad $\mathrm{B}$ et $\mathrm{al}^{26}$ & 144 & 144 & - & 52 & 86.6 \\
\hline 16. & Our Study & 671 & 60 & 19 & 68.42 & 100 \\
\hline
\end{tabular}

Akerman et al ${ }^{27}$ Quoted Four Reasons for Low Sensitivity. These include

1. Tumour missed at aspiration.

2. Microscopic misinterpretation.

3. Diagnosis of cellular atypia.

4. Indeterminate diagnosis.

\section{CONCLUSION}

The present study of fine needle aspiration cytology of Thyroid Nodules comprising 671 FNA samples and subsequent HPE in 60 cases suggests the following conclusions.

- Aspiration from Thyroid Nodules formed $15.7 \%$ of the total aspiration done during.

- There is increased preponderance for non-neoplastic lesion.

- Thyroid nodules were commonly observed in females in 603 cases and most were in the age group 20-40 yrs.

- Malignant tumours constitute $73.00 \%$ among the neoplastic lesions of the thyroid.

- Papillary carcinoma is the most common of all malignant neoplasms.

- In 10 cases of follicular neoplasm cytologically diagnosed, 8 cases were confirmed as adenomas including one case as HTA (Hyalinizing Trabecular Adenoma) in histopathological examination and the rest 2 cases turned out to be follicular carcinoma.

- The specificity and sensitivity of FNA and HPE correlation in nodular thyroid lesion are in acceptable range in our study.

Fine needle aspiration cytology is a simple, safe, cost effective diagnostic modality in the investigation of thyroid disease with high specificity and accuracy.

A benign fine needle aspiration cytology diagnosis should be viewed with caution, as false negative results do occur and the patient should be followed up with repeated aspirations to rule out missed neoplasm.

In recent trends, fine needle aspiration cytology has become an invaluable and minimal invasive procedure for screening or diagnosis of patients with thyroid nodule to guide the surgeons.

\section{REFERENCES}

1. Svante OR, Gregory SF, Darrell W. Manual and atlas of fine needle aspiration cytology. United States, Philadelphia: Elsevier Churchill Livingstone 2005; $4^{\text {th }}$ edn.

2. Caplan RH, Strutt PJ, Kisken WA, et al. Fine needle aspiration biopsy of thyroid nodules. Wis Med J 1991;90(6):285-8.

3. Gupta M, Gupta S, Gupta VB. Correlation of FNAC with histopathology in the diagnosis of solitary thyroid nodule. Journal of Thyroid Research Article ID-379051, 2010;Pgs. 5

4. Suen KC. Fine needle aspiration biopsy of the thyroid nodule. CMAJ 2002;167(5):491-5.

5. Dorairajan N, Jayashree N. Solitary nodule of the thyroid and the role of fine needle aspiration cytology in diagnosis. J Indian Med Assoc 1996;94(2):50-2.

6. Sarda AK, Gupta A, Jain PK, et al. Management options for solitary thyroid nodules in an endemic goitrous area. Postgrad Med J 1997;73(863):560-4.

7. Das DK, Khanna CM, Tripathi RP, et al. solitary nodular goitre. review of cytomorphologic features in 441 cases. Acta Cytol 1999;43(4):563-74.

8. Gupta C, Sharma VK, Agarwal AC, et al. Fine needle aspiration cytology of solitary nodule of thyroid and its histopathological correlation. Journal of Cytology 2001;18(3):151-6.

9. Kaur K, Sonkhya N, Bapna AS, et al. A comparative study of fine needle aspiration cytology: a prospective analysis of fifty cases. Indian Journal of Otolaryngology \& Head \& Neck Surgery 2002;54(2):96-101.

10. Duek SD, Goldenberg D, Linn S, et al. The role of FNAC and intraoperative frozen section in the surgical management of solitary thyroid nodules. Surg Today 2002;32(10):857-61.

11. Hurtado- Lopez LM, Arellano -Mantanos S, Torres - Acosta EM, et al. Combined use of fine needle aspiration biopsy, MIBI scans and frozen section biopsy offers the best diagnostic accuracy in the assessment of the hypofunctioning solitary thyroid nodule. Eur J Nucl Med Mol Imaging 2004;31(9):1273-9. 
12. Talepoor M, Karbankhsh M, Mirzali FA, et al. Management of solitary thyroid nodules: the dilemma of multinodular goitre as false positive cases. www.priory.com 1/1/2005 http:www.http:/priory.com/med/thyroid nodule.html (216/2005).

13. Nggada HA, Musa AB, Gali BM, et al. Fine needle aspiration cytology of thyroid nodules. A Nigerian tertiary hospital experience. The internet Journal of cardiovascular Research 2006.

http:// www. ispub. com/ ostia/index/pbp?xmllfilepathjournals/ijpa/Vol5nl/thyroid xml/

14. Prakash HM. Panorama of solitary thyroid nodule. International Journal of Medical Health Science 2012;1(1):19-26.

15. Jayaram G, Iyenger KR, Sthaneshwar P, et al. Atlas and text of thyroid cytology. New Delhi: Arya Publications 2006;24-6.

16. Gardiner GW, de Souza FM, Carydis B, et al. Fine needle aspiration biopsy of the thyroid gland: results of a five year experience and discussion of its clinical limitations. J Otolaryngol 1986;15(3):161-5.

17. Hawkins F, Bellido D, Bernal C, et al. Fine needle aspiration biopsy in the diagnosis of thyroid cancer and thyroid disease. Cancer 1987;59(6):1206-9.

18. Khafagi F, Wright G, Castles $\mathrm{H}$, et al. Screening for thyroid malignancy: the role of fine- needle biopsy. Med J Aust 1988;149(6);302-3, 306-7.
19. Hall TL, Layfield LJ, Philippe A, et al. Sources of diagnostic error in FNAC of the thyroid. Cancer 1989;63(4):718- 25.

20. Altavilla G, Pascale M, Nenci I. Fine needle aspiration cytology of thyroid gland diseases. Acta Cytol 1990;34(2):251-6.

21. Gharib H, Goellner JR, Zinsmeister AR, et al. Fine needle aspiration biopsy of the thyroid. The problem of suspicious cytologic findings. Ann Intern Med 1984;101(1):25-8.

22. Aggarwal SK, Jayaram G, Kakar A, et al. FNA cytologic diagnosis of the solitary cold thyroid nodule. Comparison with ultrasonography, radionuclide perfusion study and xeroradiography. Acta Cytol 1989;33(1):41-7.

23. Bapat RD, Shah SH, Relekar RG, et al. Analysis of 105 uninodular goitres. J Post grad Med 1992;38(2):60-1.

24. Cap J, Ryska A, Rehorkova P, et al. Sensitivity and specificity of FNAC of the thyroid: clinical point of view. Clinical Endocrinology 1999;51(4):509-15.

25. Holleman F, Hoekstra JB, Ruitenberg HM. Evaluation of FNAC in the diagnosis of thyroid nodules. Cytopathology 1995;6:175-86.

26. Mundasad B, Mcallister I, Carson J, et al. Accuracy of fine needle aspiration cytology in diagnosis of thyroid swellings. Internet Journal of Endocrinology 2006;2(2):2.

27. Akerman M, Tennvall J, Biorklund A, et al. Sensitivity and specificity of fine needle aspiration cytology in the diagnosis of tumours of the thyroid gland. Acta Cytol 1985;29(5):850-5. 